\title{
PENGEMBANGAN MODUL KIMIA SMA BERBASIS PROBLEM BASED LEARNING (PBL) PADA MATERI KELARUTAN DAN TETAPAN HASIL KALI KELARUTAN
}

\author{
Amalia Fuji Lestari ${ }^{1}$, Hadi Kusuma Ningrat ${ }^{1}$, Devi Qurniati ${ }^{1}$ \\ ${ }^{1}$ Tadris Kimia, FTK UIN Mataram, Mataram. Email: \\ chemistrydevi@uinmataram.ac.id
}

\section{Abstrak}

Bahan ajar berguna untuk mengembangkan wawasan terhadap proses pembelajaran yang ditempuh, menjadi panduan belajar dan langkah-langkah operasional untuk menelusuri secara lebih teliti materi secara tuntas. Penelitian ini bertujuan untuk mengetahui kelayakan penggunaan dan kepraktisan modul berbasis PBL. Penelitian ini telah dilakukan di kelas XI MIA 1 MA Qamarul Huda Bagu Lombok Tengah pada materi kelarutan dan tetapan hasil kali kelarutan. Pengembangan dilakukan dengan menggunakan model Dick\&Carrey. Evaluasi dilakukan dengan menggunakan metode evaluasi formatif tessmer. Data dilakukan melalui penilaian validator dan siswa, wawancara dan pengisian angket oleh guru mata pelajaran. Hasil penelitian menunjukkan bahwa kelayakan modul berdasarkan validator ahli materi adalah $74,28 \%$ dengan kategori cukup valid dan belum layak, sedangkan hasil validasi ahli bahasa diperoleh skor $87,5 \%$ dengan kategori valid dan layak, dan hasil validasi ahli media diperoleh skor $48 \%$ dengan kategori sangat tidak valid dan sangat tidak layak. Berdasarkan hasil uji coba perorangan diperoleh skor sebesar 73,33\% dengan kategori cukup praktis, hasil uji coba kelompok kecil diperoleh hasil $78 \%$ dengan kategori praktis, dan hasil uji coba lapangan diperoleh hasil $94,37 \%$ dengan kategori sangat praktis. Berdasarkan hasil penelitian disimpulkan bahwa pengembangan modul kimia SMA berbasis PBL pada materi kelarutan dan tetapan hasil kali kelarutan layak dan praktis digunakan sebagai bahan ajar SMA/MA sederajat.

Kata Kunci: Pengembangan modul, kepraktisan, kelayakan. 


\section{PENDAHULUAN}

Bahan ajar adalah seperangkat sarana atau sumber belajar yang sangat penting untuk mendukung terwujudnya tujuan pembelajaran yang diharapkan. Bahan ajar dapat digunakan sebagai pengembang wawasan terhadap proses pembelajaran yang ditempuh, menjadi panduan atau acuan dalam belajar mengajar dan langkah-langkah operasional untuk menelusuri materi secara lebih teliti dan tuntas. Bahan ajar dapat dikembangkan dalam berbagai bentuk yang disesuaikan dengan kebutuhan dan karakteristik materi yang akan disajikan. Pengembangan bahan ajar harus berdasarkan prasyarat dari badan yang berwewenang yaitu Badan Standar Nasional Pendidikan (BSNP), dan kurikulum yang berlaku. Pengembangan bahan ajar melibatkan sejumlah langkah yang mesti ditempuh oleh seorang pengembang. Menurut panduan pengembangan bahan ajar yang diterbitkan Depdiknas, ada 3 (tiga) tahapan pokok yang harus dilalui untuk mengembangkan sebuah bahan ajar, yaitu analisis kebutuhan bahan ajar, memilih sumber belajar, dan menyusun peta bahan ajar berdasarkan struktur masingmasing bentuk bahan ajar (Depdiknas).

Bahan ajar dapat berupa buku paket, LKS (lembar kerja siswa), handout, modul, rencana. pembelajaran (RP), satuan pelajaran (lesson plan) (Daryanto,2015). Salah satu bahan ajar yang dapat dikembangkan adalah modul pembelajaran. Modul pada dasarnya adalah sebuah bahan ajar yang disusun secara sistematis dengan bahasa yang mudah dipahami oleh siswa sesuai tingkat pengetahuan dan umur siswa itu sendiri, agar siswa dapat belajar sendiri 
(mandiri) dengan bimbingan yang minimal dari pendidik. Modul dapat membantu peran guru dalam proses pembelajaran, karena peran guru di kelas dapat diminalisir ketika menggunakan modul sehingga pembelajaran lebih berpusat pada siswa dan guru hanya sebagai fasilitator dalam proses pembelajaran (Vembrianto, 1985). Pembelajaran menggunakan modul juga dapat menjadikan pembelajaran lebih efisien, efektif dan relevan. Hadirnya modul dalam proses pembelajaran sangat membantu siswa lebih memahami materi yang dipelajari jika dibandingkan dengan pembelajaran konvensial yang cenderung klasikal (Wena, 2012).

Pembelajaran berbasis masalah (problem based learning), selanjutnya disingkat $\mathrm{PBL}$, merupakan salah satu model pembelajaran inovatif yang dapat memberikan kondisi belajar aktif kepada siswa. Model pembelajaran ini sangat mendukung keberlagsungan pembelajaran yang menggunakan kurikulum 2013 karena problem based learning (PBL) adalah suatu model pembelajaran yang melibatkan siswa untuk memecahkan suatu masalah melalui tahaptahap metode ilmiah sehingga siswa dapat mempelajari pengetahuan yang berhubungan dengan masalah tersebut dan sekaligus memiliki keterampilan untuk memecahkan masalah (Mufarokah, 2013).

Beberapa peneliti terdahulu telah mencoba menerapkan model problem based learning (PBL) dengan media bahan ajar berupa modul yang memiliki dampak positif terhadap kegiatan pembelajaran yakni pada penelitian yang dilakukan oleh Sunaringtyas (2015) modul 
kimia berbasis masalah pada materi konsep mol dinyatakan layak untuk digunakan dalam proses pembelajaran dan efektif dalam meningkatkan keterampilan, sikap dan hasil belajar siswa (Sunaringtyas, 2015).

Berdasarkan hasil observasi awal yang telah pengembang lakukan di MA Qamarul Huda Bagu Lombok Tengah, observasi dilakukan dengan cara mewawancarai guru kimia yang mengajar di kelas XI dan mengisi angket guru yang telah disiapkan oleh pengembanng terkait bahan ajar dan pembelajar/peserta didik. Peneliti memperoleh informasi bahwa bahan ajar kimia yang digunakan di MA Qamarul Huda Bagu Lombok Tengah berupa buku paket, LKS dan handout. Materi pembelajaran yang memiliki tingkatan kesulitan pertama yang dialami siswa adalah materi kelarutan dan tetapan hasil kali kelarutan (Aprianti, 2019). Hal tersebut dapat dilihat melalui angket yang diisi oleh guru mata pelajaran kimia kelas XI MIA. Ketiga bahan ajar yang digunakan belum ada yang membahas secara khusus tentang materi kelarutan dan tetapan hasil kali kelarutan. Metode ceramah yang digunakan oleh guru cenderung membuat siswa kurang aktif dalam kegiatan pembelajaran, sehingga peneliti mengembangkan bahan ajar yang belum pernah dikembangkan di sekolah tersebut yaitu bahan ajar berupa modul berbasis problem based learning (PBL).

Berdasarkan uraian di atas, peneliti tertarik melakukan penelitian pengembangan yang berjudul "Pengembangan Modul Kimia SMA Berbasis Problem Based Learning (PBL) 
pada Materi Kelarutan (s) dan Tetapan Hasil Kali Kelarutan $\left(K_{s p}\right)$ ".

\section{METODE}

Jenis penelitian yang pengembang gunakan adalah penelitian pengembangan yang bertujuan untuk menghasilkan suatu perangkat pembelajaran berupa modul kimia SMA berbasis Problem Based Learning (PBL) yang memenuhi kriteria layak dan praktis. Subjek penelitian yang digunakan adalah siswa kelas XI MIA 1 MA Qamarul Huda Bagu Lombok Tengah. Prosedur penelitian yang dilakukan sesuai dengan model pengembangan Dick \& Carrey yang dimodifikasi dengan evaluasi formatif tessmer yang terdiri dari 10 (sepuluh) tahapan yaitu: analisis kebutuhan dan tujuan, analisis pembelajaran, analisis pembelajar/peserta didik, merumuskan tujuan performasi, mengembangkan instrumen, mengembangkan strategi pengembangan, mengembangkan dan memilih bahan pelajaran, merancangdan melakukan evaluasi formatif, melakukan revisi, evaluasi sumatif. Pengembangan modul ini hanya menguji kelayakan dan kepraktisan sementara uji sumatif dilakukan untuk menguji keefektifan.

Data-data yang diperoleh dari hasil review oleh ahli dan uji coba produk pengembangan ini menggunakan teknik analisis statistik deskriptif. Teknik analisis statistik deskriptif digunakan untuk mengolah data yang diperoleh melalui angket dalam bentuk deskriptif persentase. Untuk melihat kelayakan dan kepraktisan modul berdasarkan penilaian 
validator ahli dan pengguna (siswa) digunakan rumus sebagai berikut (Fahmi, 2015):

Persentase kelayakan dan kepraktisan $=P=\frac{\sum \mathrm{x}}{\sum \mathrm{xi}} \mathrm{x} 100 \%$

Keterangan:

$\mathrm{P}=$ Hasil Presentase

$\sum \mathrm{x} \quad=$ Jumlah skor yang diperoleh

$\sum \mathrm{xi}=$ Jumlah skor maksimal

Untuk dapat memberikan makna terhadap hasil penelitian modul, maka digunakan ketetapan sebagai berikut (Rahmayanti, 2015):

Tabel 1. Kategori Persentase Kelayakan dan kepraktisan Modul Pembelajaran Kimia

\begin{tabular}{|c|c|c|c|}
\hline No. & $\begin{array}{c}\text { Tingkat } \\
\text { Pencapain }\end{array}$ & Kualifikasi & Keterangan \\
\hline 1. & $90-100 \%$ & Sangat baik & Tidak perlu revisi \\
\hline 2. & $75-89 \%$ & Baik & Tidak perlu revisi \\
\hline 3. & $64-74 \%$ & Cukup & Direvisi \\
\hline 4. & $55-64 \%$ & Kurang & Direvisi \\
\hline 5. & $0-54 \%$ & Sangat kurang & Direvisi \\
\hline
\end{tabular}

\section{HASIL DAN PEMBAHASAN}

Data hasil pengembangan modul kimia SMA berbasis problem based learning (PBL) ini didapatkan melalui evaluasi formatif yang dikelompokkan menjadi 2 (dua) bagian yaitu: Data evaluasi pertama yang didapatkan melalui hasil penilaian uji validasi oleh ketiga validator yaitu validator ahli 
media, ahli bahasa dan ahli materi untuk menguji kelayakan modul kimia SMA berbasis problem based learning (PBL) pada materi kelarutan dan tetapan hasil kali kelarutan yang telah dikembangkan. Modul yang dikembangkan harus diuji cobakan terlebih dahulu oleh ketiga validator. Apabila validator sudah dinyatakan layak untuk diuji cobakan kepada siswa (pengguna), maka modul tersebut boleh diuji cobakan terhadap siswa (pengguna) untuk mengetahui bagaimana kepraktisan modul yang dikembangkan.

Data evaluasi kedua didapatkan dari hasil penilaian uji coba pengguna (siswa) melalui 3 (tiga) tahapan yaitu uji coba perorangan, uji coba kelompok kecil dan uji coba lapangan pada kelas XI MIA 1 MA Qamarul Huda Bagu Lombok Tengah guna untuk mengetahui bagaimana kepraktisan modul kimia SMA berbasis problem based learning (PBL) pada materi kelarutan dan tetapan hasil kali kelarutan yang dikembangkan.

Uji coba perorangan (one to one trying out) bertujuan untuk mengidentifikasi kesalahan dan kekurangan dalam modul serta untuk mendapatkan tanggapan siswa terhadap produk pengembangan. Uji coba ini dilakukan terhadap tiga orang siswa kelas XI MIA 1 di MA Qamarul Huda Bagu Lombok Tengah. Ketiga orang siswa membaca atau mempelajarinya modul pembelajaran yang dikembangkan. Selanjutnya ketiga siswa tersebut diberikan angket untuk menilai modul kelarutan (s) dan tetapan hasil kali kelarutan $\left(K_{s p}\right)$ yang dikembangkan.

Uji coba kelompok kecil (small group try out) bertujuan untuk mengidentifikasikan kesalahan dan kekurangan dalam 
modul pembelajaran yang telah direvisi setelah diuji cobakan terhadap ketiga siswaketika uji coba perorangan. Uji coba ini melibatkan 9 (Sembilan) orang siswa kelas XI MIA 1 di MA Qamarul Huda Bagu Lombok Tengah. Pengembang mengumpulkan data hasil penilaian siswa melalui angket dalam bentum skala likert.

Setelah melalui uji coba perorangan dan uji coba kelompok kecil, selanjunya modul yang dikembangkan diuji cobakan terhadap seluruh siswa kelas XI MIA 1 MA Qamarul Huda Bagu Lombok Tengah. Uji coba ini dinamakan uji coba lapangan (field try out) yang bertujuan untuk menguji kelayakan modul kimia yang dikembangkan serta untuk mendapatkan tanggapan siswa melalui angket skala liket yang telah disiapkan pengembang. Siswa diminta untuk membaca atau mempelajari modul kimia yang dikembangkan agar dapat memberikan penilaian terhadap modul yang dikembangkan. Hasil uji formatif tersebut dapat dilihat pada tabel di bawah ini: 
Tabel 2. Hasil Uji Formatif

\begin{tabular}{|c|c|c|}
\hline Statistik & Hasil Uji Coba & Kategori \\
\hline Ahli Materi/lisi & $74,28 \%$ & Cukup \\
\hline Ahli Bahasa & $87,5 \%$ & Baik \\
\hline Ahli Media & $48 \%$ & Sangat Kurang \\
\hline Uji Perorangan & $73,33 \%$ & Cukup \\
\hline Uji Kelompok Kecil & $78 \%$ & Baik \\
\hline Uji Lapangan & $94,37 \%$ & Sangat baik \\
\hline
\end{tabular}

Berdasarkan tabel diatas, dapat dilihat bahwa setelah diuji cobakan oleh ketiga validator yaitu ahli materi/isi modul yang dikembangkan sudah tergolong ke dalam kategori cukup dan harus direvisi terlebih dahulu baru boleh diuji cobakan terhadap siswa. Ahli bahasa menilai bahwa bahasa dari modul yang dikembangkan sudah tergolong ke dalam kategori baik dan boleh diuji cobakan tanpa harus revisi terlebih dahulu. Sementara ahli media menyarankan untuk merevisi desain modul terlebih dahulu karena modul yang dikembangkan sangat tidak menarik sehingga validator ahli media memberikan nilai yang sangat minim.

Setelah modul direvisi, modul tersebut dinyatakan layak untuk diuji cobakan terhadap siswa (pengguna). Dapat dilihat pada tabel di atas, bahwa hasil uji coba dari uji perorangan masih termasuk ke dalam kategori cukup yang berarti bahwa modul tersebut harus di revisi terlebih dahulu. Selanjutnya, tanggapan siswa mengenai modul yang dikembangkan pada uji coba kelompok kecil bahwa modul tersebut dinyatakan baik. Namun agar mendapatkan hasil 
yang maksimal, modul tersebut direvisi kembali untuk diujicobakan terhadap siswa dalam uji coba lapangan.

Terlihat pada tabel di atas, bahwa hasil akhir pada saat uji coba lapangan sudah memuaskan bagi siswa (pengguna) maupun pengembang. Modul yang dikembangkan sudah dinyatakan sangat baik sehingga modul tersebut dinyatakan praktis untuk digunakan oleh siswa (pengguna) maupun guru dalm proses pembelajaran.

\section{KESIMPULAN}

Berdasarkan hasil penelitian disimpulkan bahwa, setelah melewati uji validasi dan revisi dari ke-3 (tiga) ahli yaitu ahli materi/isi, ahli bahasa dan ahli media, modul kimia SMA berbasis problem based learning (PBL) pada materi kelarutan dan tetapan hasil kali kelarutan dinyatakan layak digunakan sebagai tambahan bahan ajar siswa kelas XI SMA/MA. Sedangkan berdasarkan hasil uji coba formatif yang telah dilakukan, modul kimia SMA berbasis problem based learning ( $\mathrm{PBL}$ ) pada materi kelarutan dan tetapan hasil kali kelarutan dinyatakan praktis digunakan sebagai tambahan bahan ajar siswa kelas XI SMA/MA dengan presentase nilai $94,37 \%$.

\section{DAFTAR PUSTAKA}

Aprianti, R. (2019). Pengisian angket Guru. Lombok Tengah: MA Qamarul Huda Bagu. 
Daryanto. (2015). Strategi dan Tahapan Mengajar Bekal Keterampilan Dasar Bagi Guru. Bandung: Cvyrama Widya.

Fahmi, L. (2015). Pengembangan Buku Ajar Berbasis Inquiri Pada Materi Keanekaragaman Hayati untuk Siswa Kelas $X$ di MA Al-Ikhsaniyah Sisik Timur Kec. Pringgarata Tahun Pelajaran 2015/2016. (Skripsi). Mataram: Universitas Islam Negeri Mataram.

Mufarokah, A. (2013). Strategi \& Model-Model Pembelajaran. Tulung Agung: STAIN Tulungagung Press.

Rahmayanti, D. (2015). Pengembangan LKS (Lembar Kerja Siswa) Berbasis Problem Based Learning (PBL) pada Materi Keanekaragaman Hayati untuk Siswa Kelas $X$ di SMAN 1 Montong Gading Lombok Timur Tahun Pelajaran 2015/2016. (Skripsi). Mataram : Intitut Keguruan dan Ilmu Pendidikan Mataram.

Sunaringtyas. (2015). Pengembangan Modul Kimia Berbasis Masalah pada Materi Konsep Mol KelasX SMA/MA Sesuai K-13. (Skripsi). Surakarta: Universitas Sebelas Maret.

Tim Penyusun Direktorat Pembinaan Sekolah Menengah Atas Dirjen Manajemen Pendidikan Dasar dan Menengah Depdiknas. Panduan Pengembangan Bahan Ajar. Jakarta: Depdiknas.

Vembriarto, S.T. (1985). Pengantar Pengajaran Modul. Yogyakarta: Yayasan Pendidikan Paramita. 
Wena, M. (2012). Strategi Pembelajaran Inovatif Kontemporer; Suatu Tinjauan Konseptual Operasional. Jakarta: Bumi Aksara. 